Iva Pasini Tržec - Ljerka Dulibić

Strossmayerova galerija starih majstora, Hrvatska akademija znanosti i umjetnosti

\title{
O provenijenciji nekoliko slika pristiglih u Strossmayerovu galeriju odlukama državnih tijela FNRJ od 1948. do 1958. godine
}

\author{
Izvorni znanstveni rad - Original scientific paper \\ Primljen - Received 29. 6. 2017.
}

UDK 069.51:75-021.52(497.1)"1948/1958"

\begin{abstract}
Sažetak
Obuhvatnim istraživanjima različitih arhivskih izvora relevantnih za problematiku transfera vlasništva umjetnina neposredno prije i tijekom Drugoga svjetskoga rata te u poslijeratnom razdoblju utvrđeni su raniji vlasnici i/ili neke od okolnosti promjena vlasništva nekoliko slika koje su u zbirni fond Strossmayerove galerije starih majstora HAZU pri-
\end{abstract}

stigle temeljem odluka državnih tijela Federativne Narodne Republike Jugoslavije izmedu 1948. i 1958. godine. Istraživanje sudbine tih slika prije i tijekom Drugoga svjetskoga rata dopunjeno je analizom arhivskih dokumenata koji svjedoče o procesu poslijeratne muzealizacije brojnih umjetnina u hrvatskim muzejima.

Ključne riječi: Pieter Jansz. Quast, aukcijska kuća Dorotheum, Jacques Goudstikker, Jacopo Palma Ml., Eduard Polak, Friedrich von Amerling, Eugen Kaufmann, dvorac Gornja Radgona

Preustrojem jugoslavenske državne uprave početkom pedesetih godina 20. stoljeća poslove ministarstava, odnosno nekadašnjih komiteta, preuzimaju novoformirani Savjeti na saveznoj i republičkim razinama. ${ }^{1} \mathrm{U}$ travnju 1951. oformljen je Savjet za nauku i kulturu Federativne Narodne Republike Jugoslavije, ${ }^{2}$ a u svibnju iste godine i Savjet za prosvjetu, nauku i kulturu Narodne Republike Hrvatske (1951.-1956.). ${ }^{3}$ Nakon ukinuća Savjeta za prosvjetu, nauku i kulturu NRH u lipnju 1956. godine poslove iz nadležnosti toga tijela preuzeli su Savjet za prosvjetu (1956.-1963.), Savjet za kulturu i nauku (1956.-1961.) i Savjet za kulturu (1961.-1963.). ${ }^{4}$

Savjeti su, kao sljednici ministarstva, upravljali obrazovnim sustavom, vodili poslove iz područja kulture i umjetnosti te skrb o ustanovama kulturno-umjetničkoga tipa, između ostaloga i (su)financirajući nabave umjetnina za muzejske institucije. Zahvaljujući financijskoj pomoći Savjeta za kulturu i nauku, za Strossmayerovu je galeriju krajem 1959. godine otkupljena od Miodraga Obradovića iz Beograda slika Fantastični krajolik pripisana Salvatoreu Rosi, ${ }^{5}$ a financijska pomoć Savjeta zabilježena je i prilikom otkupa slike Andrije Medulića Izak blagoslivlja Jakova 1961. godine. ${ }^{6}$

Savjeti su otkupljivali i djela suvremenih umjetnika, koja su potom iz posjeda Savjeta poklanjana galerijskim odnosno muzejskim institucijama ili pak značajnim pojedincima. Tako je 1954. godine Savjet za prosvjetu, nauku i kulturu $» u$ povodu proslave pedesetgodišnjice upisa našeg zemljaka, velikog umjetnika Zlatka Balokovića u Muzičku školu Hrvatskog glazbenog zavoda u Zagrebu « odlučio da se tom istaknutom glazbeniku »u znak pažnje i poštovanja daruje « slika Otona Glihe Crne smokve »iz posjeda ovog Savjeta «, napomenu odnosno uputu kako se slika "ustupa besplatno i briše iz inventarske knjige Savjeta «. ${ }^{8} \mathrm{Te} 1954$. godine svjetski poznati violinist Zlatko Baloković održao je niz koncerata u Hrvatskoj, ${ }^{9}$ kojom prilikom mu je taj poklon mogao biti izravno uručen. Slika Crne smokve ušla je u fundus Strossmayerove galerije 1972. godine donacijom zbirke umjetnina Zlatka Balokovića i njegove supruge Joyce Borden. ${ }^{10}$

Nadalje, iz analize arhivskih dokumenata proizlazi da su ovlasti Savjetā obuhvaćale i distribuciju izvlaštenih umjetnina muzejima. U suradnji s nadležnim Konzervatorskim zavodom Savjet je raspoređivao "zaostale« umjetnine nekada u privatnom, najčešće židovskom vlasništvu, koje su slijedom ratnih i poslijeratnih zbivanja bile stavljene pod državnu upravu, odnosno sekvestrirane su. ${ }^{11} \mathrm{U}$ zbirni fond Strossmayerove galerije starih majstora na taj je način pristiglo nekoliko slika: odlukom Komiteta za kulturu i umjetnost 
1. Pieter Jansz. Quast, Kartaši, ulje na dasci, 32,5 × 43,5 cm, Strossmayerova galerija starih majstora HAZU, inv. br. SG-662 (foto: Fototeka Strossmayerove galerije)

Pieter Jansz. Quast, Card Players, oil on panel, $32.5 \times 43.5 \mathrm{~cm}$, Strossmayer Gallery of Old Masters, HAZU, inv. no. $S G-662$

iz Beograda, odnosno kasnijega Savjeta za nauku i kulturu FNRJ 1948. godine pristigla je slika Kartaši Pietera Jansz. Quasta, odlukom Savjeta za prosvjetu, nauku i kulturu 1954. godine slike Uznesenje Bogorodice, Bezgrešno začeće i Bogorodica Milo$s r d a$, te odlukom Savjeta za kulturu i nauku 1958. godine slika Polaganje u grob Jacopa Palme Ml. Prijašnji vlasnici i okolnosti promjena vlasnišstva tih umjet-

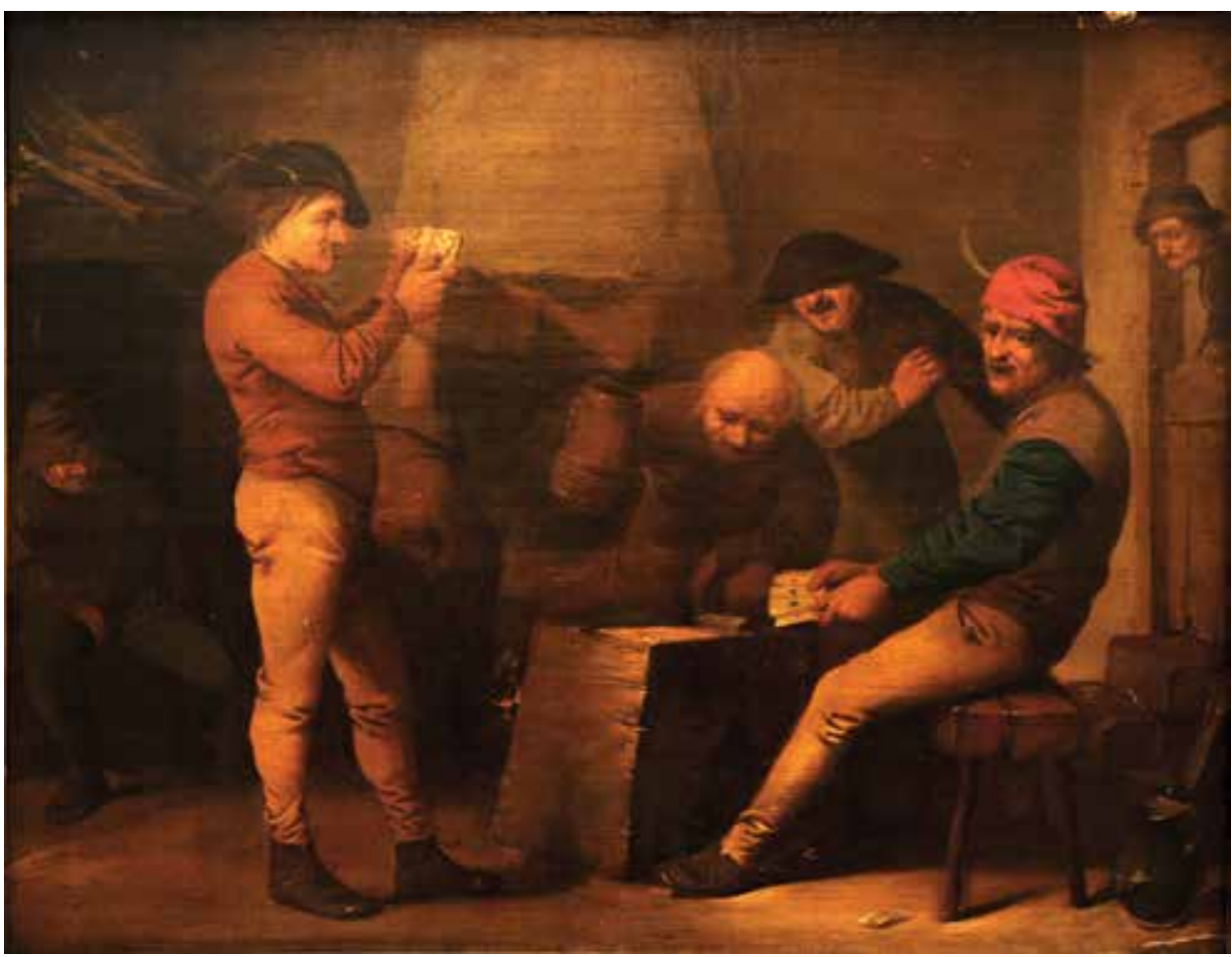
nina prije njihova ulaska u zbirni fond Strossmayerove galerije utvrđeni su tijekom recentnih obuhvatnih istraživanja različitih arhivskih izvora relevantnih za problematiku transfera vlasništva umjetnina neposredno prije i tijekom Drugoga svjetskoga rata, te u poslijeratnom razdoblju. ${ }^{12}$

\section{Kartaši Pietera Jansz. Quasta}

Sliku Kartaši (sl. 1) Strossmayerova je galerija preuzela 1948. godine od Komiteta za kulturu i umjetnost iz Beograda, kako to proizlazi iz šture potvrde o primitku umjetnine. ${ }^{13}$ Pobliže o uvjetima predaje slike Strossmayerovoj galeriji saznajemo iz dokumenta kojim su Galerija i Savjet za nauku i kulturu Vlade FNRJ, kao sljednik prijašnjeg Komiteta, podosta precizno 1952. godine uredili međusobne obaveze: slika je uvedena u inventar posuđenih umjetnina, a "posudjivač se obvezuje da neće mijenjati smještaj umjetnine bez pristanka vlasnika, kao i da je neće dalje posudjivati (...). Posudjivač snosi materijalnu i krivičnu odgovornost za umjetninu do časa vraćanja vlasniku. $\aleph^{14}$

Netom nakon primopredaje slika je uvrštena u stalni postav Strossmayerove galerije i objavljena u katalogu 1950. godine kao djelo »holandeske škole 17. stoljeća« uz napomenu o vlasništvu »Komiteta za nauku i kulturu pri vladi FNRJ« ${ }^{15} \mathrm{U}$ galerijskom katalogu iz 1967. još uvijek se bilježi vlasništvo »bivšega Komiteta za kulturu i umjetnost $«{ }^{16}$ no u katalogu izložbe Sto godina Strossmayerove galerije 1984. godine slika je evidentirana kao vlasništvo Galerije, »dar Saveta za nauku i kulturu, Beograd, 1948 «. ${ }^{17}$

Atributivno određenje postavljeno je na temelju opaski Matka Peića i Paula Coremansa, koje 1958. godine prenosi Ivy Kugly: »Na eventualnog autora ove veoma interesantne

slike upozorio me je svojedobno prof. Matko Peić, smatrajući, da bi to mogao biti Pieter Quast. Tu atribuciju prihvatio je i prof. Coremans izjavljujući, 'da je kompozicija te slike i suviše vezana uz djela Pietera Jansz. Quasta (Amsterdam 1606-1647), a da bi se to djelo moglo klasificirati samo kao rad 'holandske škole XVII. st.' «. ${ }^{18}$

Pieter Jansz. Quast amsterdamski je slikar, grafičar, crtač i kipar, koji je svoj izraz razvio prvenstveno u rodnom gradu, $s$ kratkim prekidom u Den Haagu, gdje je bio upisan u slikarsku gildu svetoga Luke. ${ }^{19}$ Glavni izvor za slikarev život i rad još je uvijek studija Abrahama Brediusa iz 1902. godine, čiji je kata$\log$ Quastovih slika i crteža u međuvremenu tek sporadično nadopunjavan. ${ }^{20}$ Quast je slikao prikaze seljaka u razonodi, vojničke prizore, elegantne razgovore te portrete, značajno upotpunjujući nizozemsko portretno i genre slikarstvo 17. stoljeća. Njegov se slikarski leksik razvija uz Adriaena Brouwera i Adriaena van Ostadea, obogaćujući prikaze humornoga lowlife genrea karikaturalnim tipološki prepoznatljivim likovima seljaka u često prenaglašenim pozama i gestama. Te odlike prepoznajemo i na slici Kartaši, gdje su u plitko definiran interijer smeđih tonova smještena sedmorica muškaraca čija je odjeća akcentuirana pokojom lokalnom bojom uz crtački istaknute nabore na pregibima draperija.

U arhivskim fondovima Strossmayerove galerije i Hrvatske akademije znanosti i umjetnosti nema nikakvih daljnjih podataka o podrijetlu slike niti okolnostima pod kojima je dospjela u vlasništvo beogradskoga Komiteta odnosno Savjeta za nauku i kulturu. Ipak, komparativnim istraživanjem cijeloga niza raznorodnih izvora moguće je utvrditi mnoge detalje njezine sudbine.

Sliku prepoznajemo na popisu imovine Ante Pavelića koja je iz rudnika soli Altaussee u Austriji odaslana 18. srpnja 1946. godine najprije u Linz, a potom u Beč i naposljetku u 


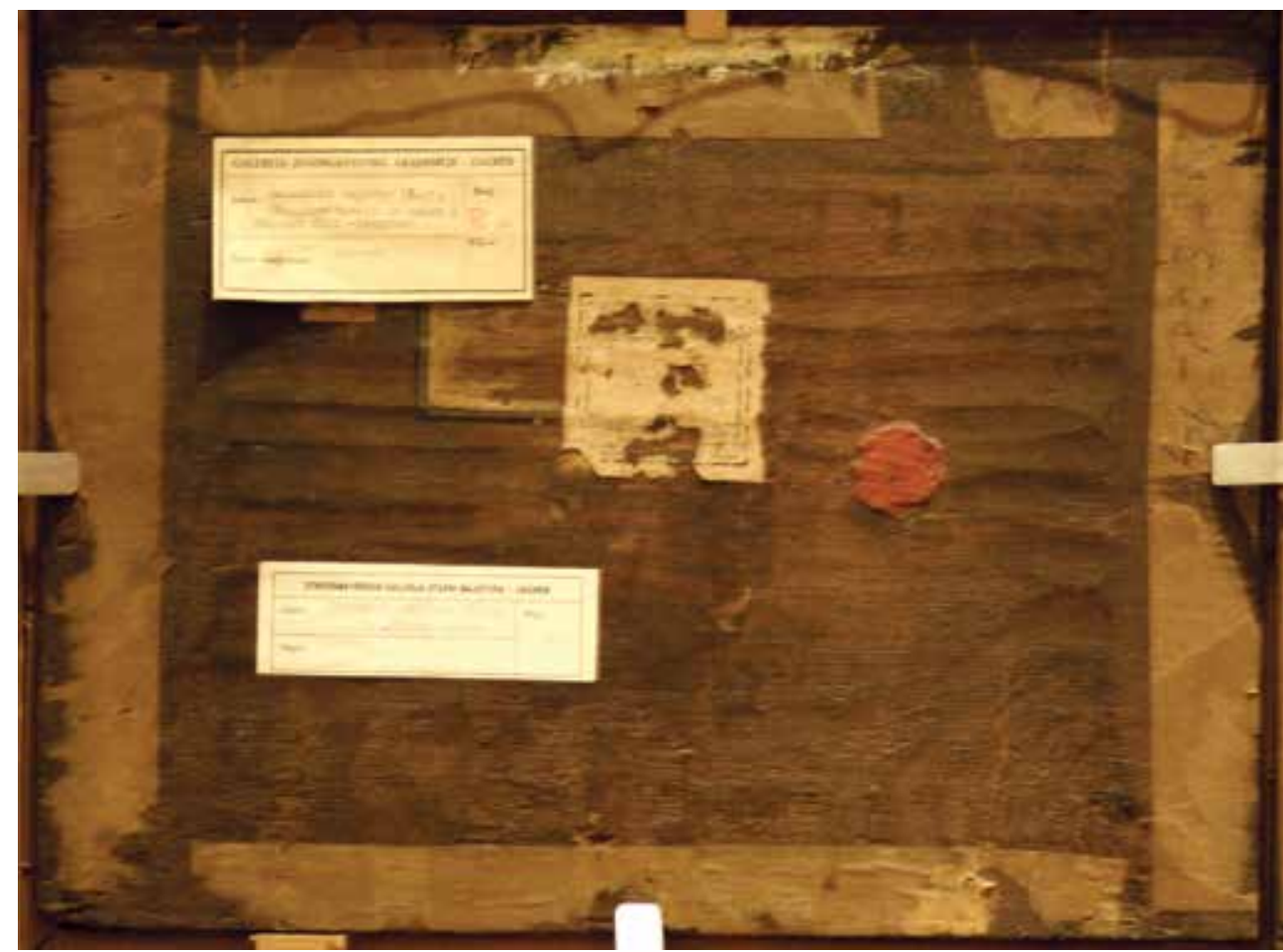

Jugoslaviju. ${ }^{21}$ Naime, prilikom preuzimanja $» 14$ boxes and 4 trunks « osobne Pavelićeve imovine, jugoslavenskom je predstavniku kao »Yugoslav property « predana i slika »Peasants playing cards «, ${ }^{22}$ kao jedini predmet na popisu »Einkäufe beim Dorotheum in Wien von Objekten, die das Dorotheum in Jugoslavien angekauft hat ${ }^{23}{ }^{23} \mathrm{U}$ tim je dokumentima slika označena brojem 215-528-14, koji je do danas sačuvan na njezinoj poleđini (sl. 2).

Tragom tih podataka bilo je moguće pronaći sliku u prodajnom katalogu Dorotheuma iz 1944. godine: navedena je pod brojem 85 , uz reprodukciju i kratki opis: »Niederländischer Maler, 1 Hälfte des 17. Jahrh., Kartenspielende Bauern in der Schenke, Öl auf Holz, $33 \times 44 \mathrm{~cm} \ll{ }^{24} \mathrm{U}$ katalogu nema nikakvih podataka o prijašnjim vlasnicima odnosno prodavatelju slike, a ostaci crvenog voštanog pečata i nekoliko ceduljica na poleđini slike više nisu čitliivi. Štoviše, teško se oteti dojmu kako su tragovi tih oznaka namjerno uništeni kako bi se onemogućila njihova čitljivost, odnosno prikrili tragovi ranije provenijencije slike. To ne čudi s obzirom na poslovanje Dorotheuma u tom razdoblju. Naime, ugledna aukcijska kuća utemeljena 1707. godine kao Kaiserlich-Königliches Versatz-, Verwahrungs- und Versteigerungsamt, koja od 1923. godine nosi ime Dorotheum, nakon pripojenja Austrije Njemačkoj podvrgnuta je nacističkoj upravi, te je preuzela monopol nad prodajom umjetnina oduzetih židovskim obiteljima i zaplijenjenima na okupiranim područjima. ${ }^{25} \mathrm{Na}$ izbor Dorotheuma kao prodajnoga centra zaplijenjene imovine nesumnjivo su utjecali višestoljetno iskustvo, profesionalnost i ugled te aukcijske kuće, čime se jamčilo postizanje visokih cijena na dražbama. U razdoblju od 1930. do 1937. godine Dorotheum je objavljivao između 20 i 33 kataloga godišnje što je činilo polovicu svih objavljenih aukcijskih kataloga u Austriji, a 1938. godine sa 67 od ukupno 76 tiskanih kataloga ostvario je potpunu prevlast na austrijskom
2. Pieter Jansz. Quast, Kartaši, poleđina

Pieter Jansz. Quast, Card Players, reverse of the painting

aukcijskom tržištu. ${ }^{26}$ Ipak, tijekom ratnih godina broj aukcija se smanjivao, te je 1944. godine tiskano samo dvanaest kataloga, a 1945. tek jedan.

Dorotheum je bio glavni partner posebne misije, tzv. "Sondertauftrag Linz«, čiji je cilj bio prikupljanje umjetnina za Führerov muzej u Linzu. Umjetnine koje bi Sonderauftrag Linz odabirao na aukcijama bile su uskladištene u posebnom Dorotheumovu spremištu, a potom bi bile slane za München.$^{27}$ Međutim, od ljeta 1944. godine umjetnine iz Dorotheumovih spremišta, a među njima i slika Kartaši koja je danas u Strossmayerovoj galeriji, prebacuju se u rudnik soli Altaussee pokraj Salzburga. Tamo su već bile pohranjene umjetnine iz austrijskih crkava, samostana i muzeja, a od veljače 1944. godine rudnik soli počeo je služiti i kao veliki repozitorij umjetnina koje su sakupljane za budući Hitlerov muzej.

Ostaje međutim nejasno kako je, točno gdje i pod kojim okolnostima Dorotheum došao u posjed slike Kartaši, posebice stoga što je riječ o jedinoj umjetnini koju je ta aukcijska kuća evidentirala kao nabavljenu u Jugoslaviji. Pretpostavljena jugoslavenska provenijencija slike dodatno intrigira s obzirom na to da možemo utvrditi njezino kretanje na tržištu umjetninama u Nizozemskoj, nekoliko desetljeća prije. Prepoznajemo je, naime, u kartičnim bilješkama nizozemskoga povjesničara umjetnosti Hofstedea de Groota, koji je zabilježio da je slika bila izložena na Goudstikkerovoj izložbi u Den Haagu 1919. godine. ${ }^{28}$

Jacques Goudstikker (1897.-1940.) jedan je od najznačajnijih nizozemskih trgovaca umjetninama starih majstora između dvaju svjetskih ratova, koji je ostao zapamćen kao prvi sakupljač ranotalijanskoga slikarstva u Nizozemskoj te uživao velik međunarodni ugled kao sakupljač i trgovac izrazito kvalitetnih slika. ${ }^{29}$ Od 1919. godine posluje u tvrtci svoga oca Eduarda, utemeljenoj još 1845 . godine, te nakon očeve smrti 1924. godine preuzima poslovanje. Središte tvrtke 1927. godine seli u Herengracht 458 u Amsterdamu te ta adresa tijekom tridesetih godina 20. stoljeća postaje prestižno stjecište umjetničkoga poslovnog i mondenog svijeta, »eine der ersten Kunstadressen Europas «. ${ }^{30} \mathrm{Od}$ samih početaka Jacques Goudstikker trudio se uzdići poslovanje na internacionalnu razinu, pri čemu započinje tiskom prodajnih kataloga na francuskom jeziku te organizacijom izložaba od Osla i Ko- 
penhagena sve do Sjedinjenih Američkih Država. Također proširuje dotadašnju ponudu nizozemskih i flamanskih slika Zlatnoga doba s nizozemskim, flamanskim, njemačkim i talijanskim slikama 14., 15. i 16. stoljeća. Nakon nesretne smrti Jacquesa Goudstikkera prilikom bijega iz Nizozemske 1940. godine, njegova je zbirka dospjela u ruke Hermanna Göringa. Nakon rata veliki broj umjetnina restituiran je $\mathrm{u}$ Nizozemsku, a postupak povrata nasljednicima trajao je do 2006. godine. ${ }^{31}$

Sliku Kartaši nalazimo u dva prodajna kataloga tvrtke Goudstikker iz 1919. godine. Navod sačuvan među kartičnim bilješkama Hofstede de Grooot potječe iz prodajnoga kataloga izložbe održane u studenom 1919. godine u studiju Pulchri u Den Haagu, ${ }^{32}$ a slika je nekoliko mjeseci prije bila ponuđena i na prodajnoj izložbi u Rotterdamu. ${ }^{33}$ Iako u tim katalozima nije reproducirana, detaljan opis i istovjetne dimenzije posve odgovaraju zagrebačkoj slici, koja je najvjerojatnije upravo ta slika Kartaša nekada na prodaji kod Goudstikkera.

Do kada je slika bila u Goudstikkerovu vlasništvu te što se $s$ njom događalo tijekom turbulentnih godina neposredno prije i tijekom Drugoga svjetskog rata, prije nego što je zatječemo 1944. godine na prodaji u Dorotheumu u Beču, odnosno 1946. godine kao nekadašnju "jugoslavensku svojinu « među slikama koje je Dorotheum deponirao u rudniku soli Altaussee, ostaje nam nepoznato.

\section{Slike trgovca Eugena Kaufmanna iz Donje Dubrave}

Turbulentni događaji ratnoga vremena bitno su odredili i sudbinu slika koje je Savjet za prosvjetu, nauku i kulturu predao Strossmayerovoj galeriji 1954. godine, temeljem rješenja o raspodjeli »slika bivšeg vlasnika Kaufmann Eugena iz Donje Dubrave, koje su prešle u vlasništvo države i preuzete iz pohrane u Hrvatskoj zemaljskoj banci d. d. u likvidaciji u Zagrebu «. ${ }^{34}$

Identifikaciju bivšega vlasnika omogućuje uvid u dokumente o utvrđivanju, popisivanju i konfisciranju njegove imovine, koji se čuvaju u arhivskom fondu Zemaljske uprave narodnih dobara u Hrvatskom državnom arhivu. Eugen Kaufmann, rođen 1887. godine, bio je većinski vlasnik tvrtke Borka za trgovinu drvom i građevnim materijalom, koju je osnovao 1939. godine zajedno s Đurom Gruberom. ${ }^{35}$ Prije osnutka samostalnoga poduzeća Kaufmann je radio kao činovnik u tvrtci Ujlaky-Hirschler i sin u Donjoj Dubravi, koja je u prvom desetljeću 20. stoljeća rukovodila šesnaest velikih pilana diljem Austro-Ugarske Monarhije, pretvorivši malo međimursko trgovište Donja Dubrava u glavno središte prometa drvom na Dravi. ${ }^{36}$ Obitelj Hirschler obilježila je gospodarski i društveni život Donje Dubrave tijekom 19. i početkom 20. stoljeća, međutim mondeni život i loše rukovođenje te velika svjetska gospodarska kriza upropastili su tvrtku. Nedugo nakon proslave stote godišnjice tvrtku krajem tridesetih godina napuštaju vjerni suradnici, a neki osnivaju i konkurentske tvrtke, poput Eugena Kaufmanna. ${ }^{37}$

U travnju 1941. godine Međimurje potpada pod okupaciju Mađarske, gdje je pod pritiskom Njemačke još 1938. godine

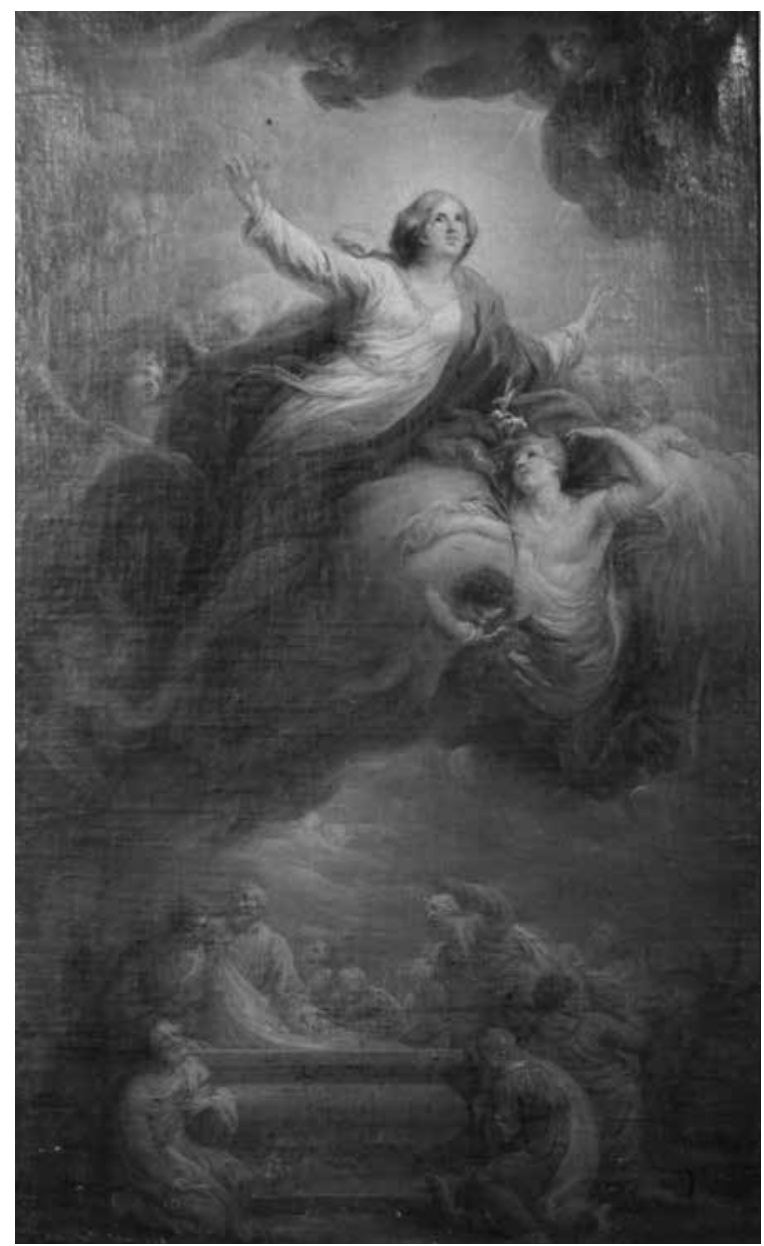

3. Uznesenje Bogorodice, arhivska fotografija (HR-HDA-1095, kutija 93)

The Assumption of the Virgin, archival photograph

započeo proces ograničavanja prava Židova. Mađarski rasni zakoni međutim nisu bili tako surovi kao nacistički njemački, pa je zakonski tretman Židova u Međimurju pod mađarskom okupacijom isprva bio mnogo blaži od onoga u Pavelićevoj NDH. ${ }^{38}$ Prvih ratnih godina Kaufmann se očito pokušava prilagoditi novouspostavljenim propisima koji su onemogućavali Židove u stjecanju nekretnina:»1942. godine kupljena je kuća br. 162 u Donjoj Dubravi, kupoprodajni ugovor glasi na ime Jelisavete Bolmanac «, a ista je Jelisaveta Bolmanac iz Donje Dubrave "prema konceptu testamenta" iz 1941. godine »doživotni uživalac cijelokupne imovine Eugena Kaufmana «. ${ }^{39}$ Popis Kaufmannove imovine evidentira uobičajen inventar građanskoga stana toga vremena. Osim namještaja, slika, grafika i akvarela suvremenih slikara te nekoliko glazbenih instrumenata, ističe se navod broj 71: »Uljene slike. Pet komada. Colli tresor Jugosl. banke Zagreb «, uz napomenu: »Od toga tri slike poklonjene 10. III. 1941..$^{40}$ Iz dodatka popisu odnosno zapisniku o preuzimanju sekvestrirane imovine vidljivo je da je Kaufmann početkom rata dvije slike darovao crkvi u Donjoj Dubravi, a jednu je poklonio Jelisaveti Bolmanac, ${ }^{41}$ pokušavajući očito takvim prijenosom imovine spasiti i svoje pokretnine. Međutim, nakon njemačke okupacije Mađarske u ožujku 1944. godine 


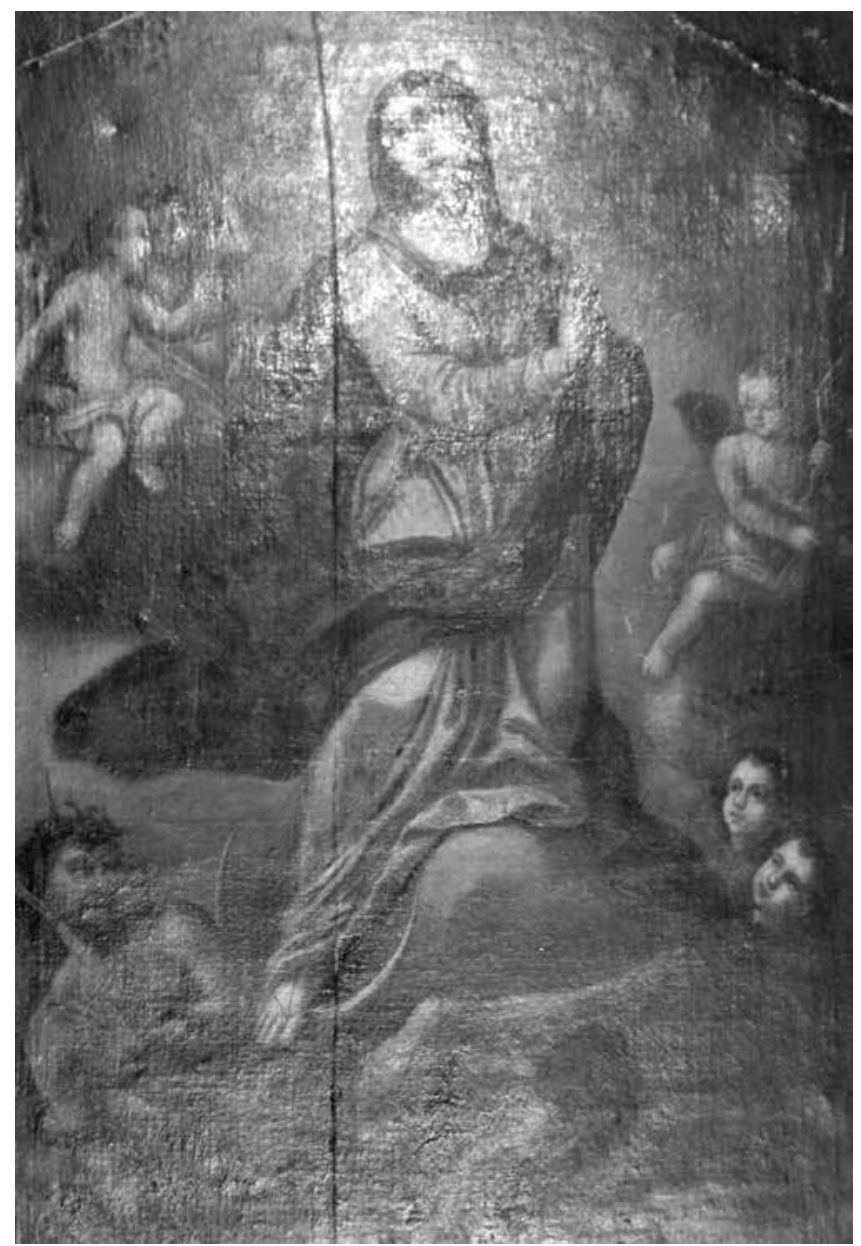

4. Bezgrešno začeće, arhivska fotografija (HR-HDA-1095, kutija 93) The Immaculate Conception, archival photograph

donosi se cijeli niz novih antižidovskih uredbi te nalaže deportacija svih Židova s anektiranih područja. ${ }^{42}$ Tijekom te posljednje eskalacije progona stradao je i Eugen Kaufmann, "odveden po okupatoru 1944. godine / pošto je bio Jevrej«. ${ }^{43}$

O sudbini Kaufmannovih pet »uljenih slika« pohranjenih u trezor banke pobliže saznajemo iz dokumenata Savjeta za prosvjetu, nauku i kulturu. Slike su ostale u Hrvatskoj zemaljskoj banci d. d. u likvidaciji sve do svibnja 1954. godine kada je Narodna banka FNRJ zatražila od Savjeta za prosvjetu, nauku i kulturu da ih preuzme. ${ }^{44}$ Prema uputi Savjeta preuzeo ih je Konzervatorski zavod koji je ujedno trebao predložiti ustanovu kojoj će se one dodijeliti. ${ }^{45}$ Nakon pregleda slika Konzervatorski je zavod Savjetu dostavio fotografije slika s uputom za distribuciju: tri slike religiozne tematike (sl. 3, sl. 4, sl. 5) Strossmayerovoj galeriji, a dva portreta plemića (sl. 6, sl. 7) Povijesnom muzeju. ${ }^{46}$ Slike su tim institucijama predane tijekom prosinca 1954 . godine. ${ }^{47}$

Jedna od slika religiozne tematike, Bogorodica Milosrda, ostaje nam poznata samo preko arhivske fotografije, ${ }^{48} \mathrm{u}$ Strossmayerovoj se galeriji do danas čuvaju slike Uznesenje Bogorodice (sl. 8) i Bezgrešno začeće (sl. 9), ${ }^{49}$ a u Hrvatskom povijesnom muzeju dva portreta. ${ }^{50}$ Prepoznato je da je riječ

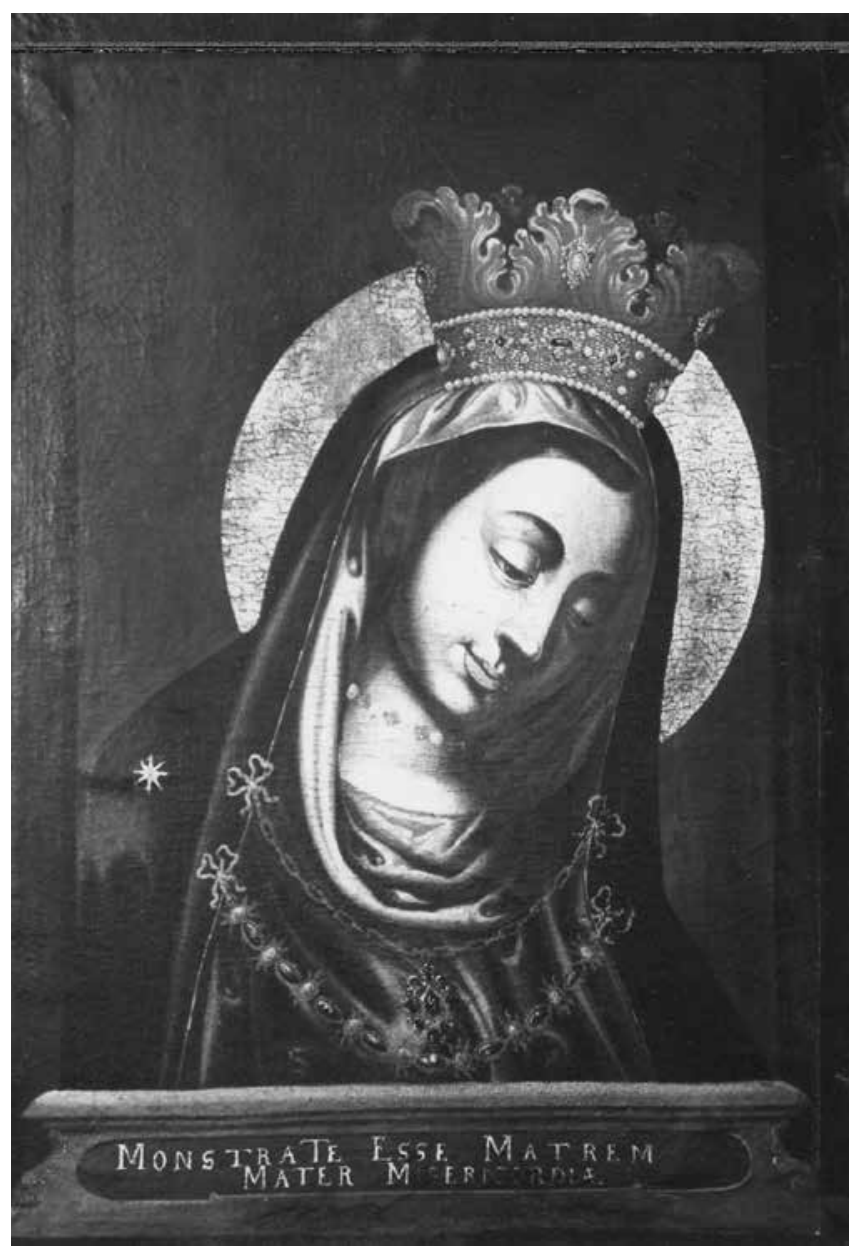

5. Bogorodica Milosta, arhivska fotografija (HR-HDA-1095, kutija 93)

Our Lady of Mercy, archival photograph

je o portretima Johanna Andrea Auersperga i Johanna Weikharda Auersperga koji su bili dio galerije portreta članova plemićke obitelji Auersperg u dvorcu Gornja Radgona. ${ }^{51}$ Inventar toga dvorca fotografirao je 1929. godine slovenski povjesničar umjetnosti France Stele neposredno prije prodaje koju je organizirao posljednji vlasnik grof Karl Chorinsky. $\mathrm{Na}$ jednoj od Steleovih fotografija prepoznaje se portret Johanna Andrea. ${ }^{52}$

Iz izvještaja o polozima Hrvatske zemaljske banke d. d. u likvidaciji iz 1946. godine proizlazi da je Eugen Kaufmann svojih pet slika položio u trezor (tada Jugoslavenske) banke 1930. godine ${ }^{53}$ dakle ubrzo nakon što je održana aukcija u dvorcu Gornja Radgona. ${ }^{54}$ U prodajnom katalogu međutim nisu navedene dimenzije slika, niti su one reproducirane, pa identifikacija Kaufmannovih slika s prikazima Bogorodice ne može biti sigurna. Ipak, u sobi broj 11 nalazimo navod u kojem se može prepoznati Uznesenje Bogorodice koje je danas u Strossmayerovoj galeriji (sl. 8): "79. oljnata slika 'Marijino vnebozetje' v pristno pozlačenem okvirju-volov. oči / Ölgemälde 'Maria Himmelfahrt' in echt vergoldetem Ochsenaugenrahmen / 3000 «. ${ }^{55}$ Slika je do danas u pozlaćenom okviru tzv. Ochsenaugenrahmen, tipičnom za austrijski 


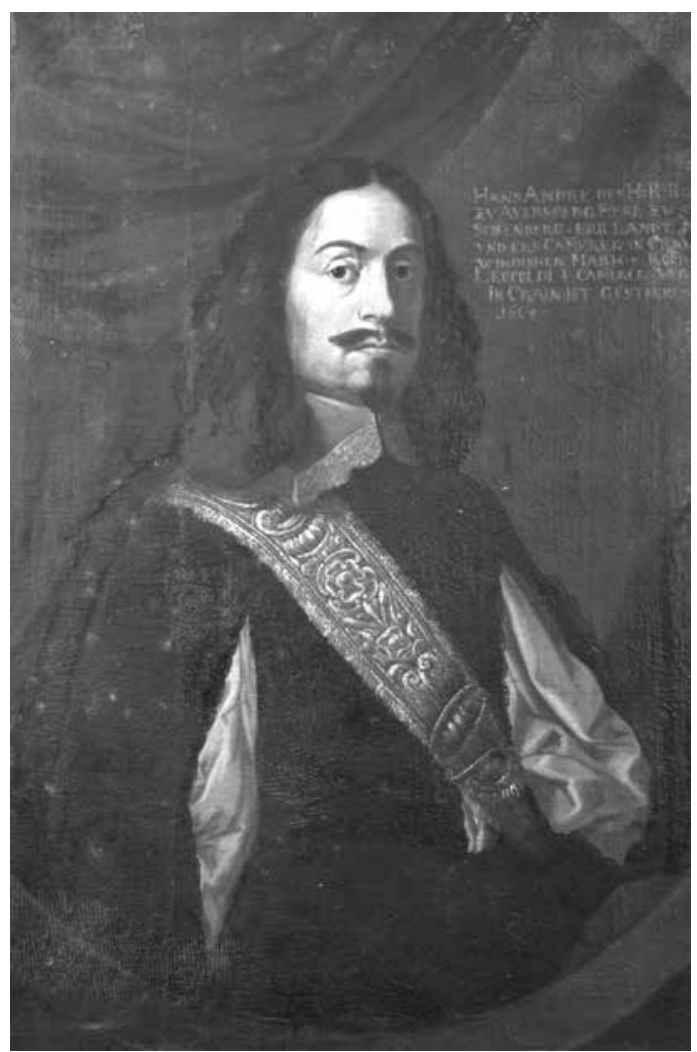

6. Johann Andre Auersperg, arhivska fotografija (HR-HDA-1095, kutija 93)

Johann Andre Auersperg, archival photograph

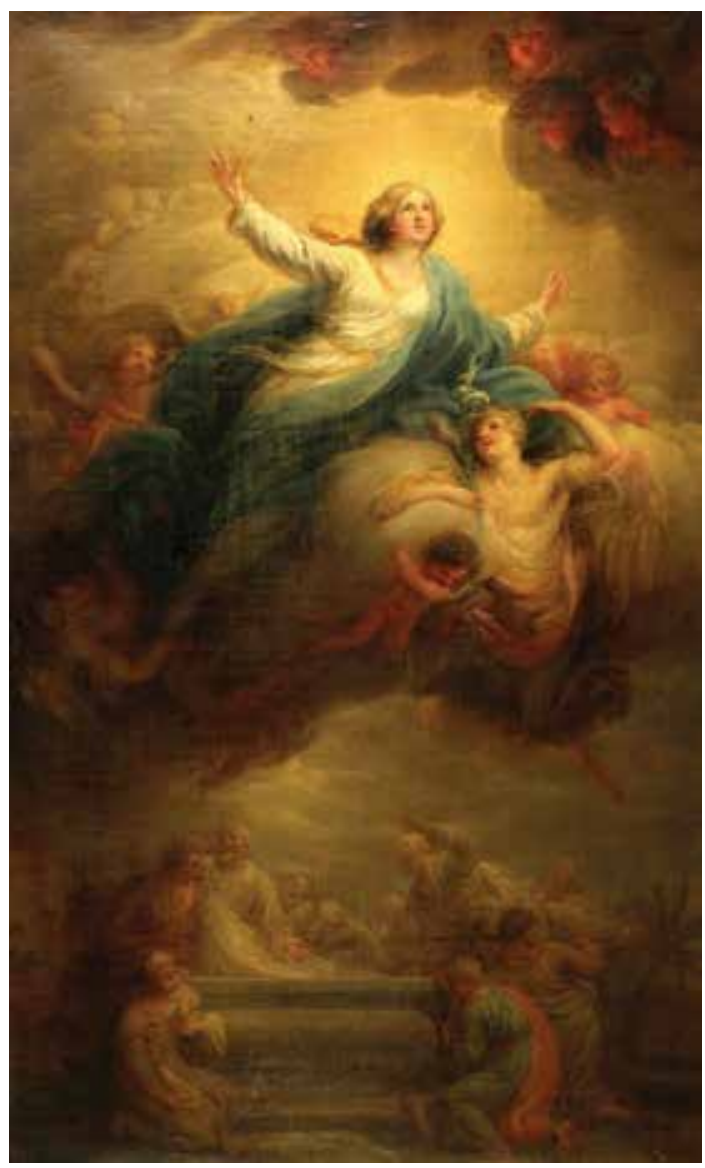

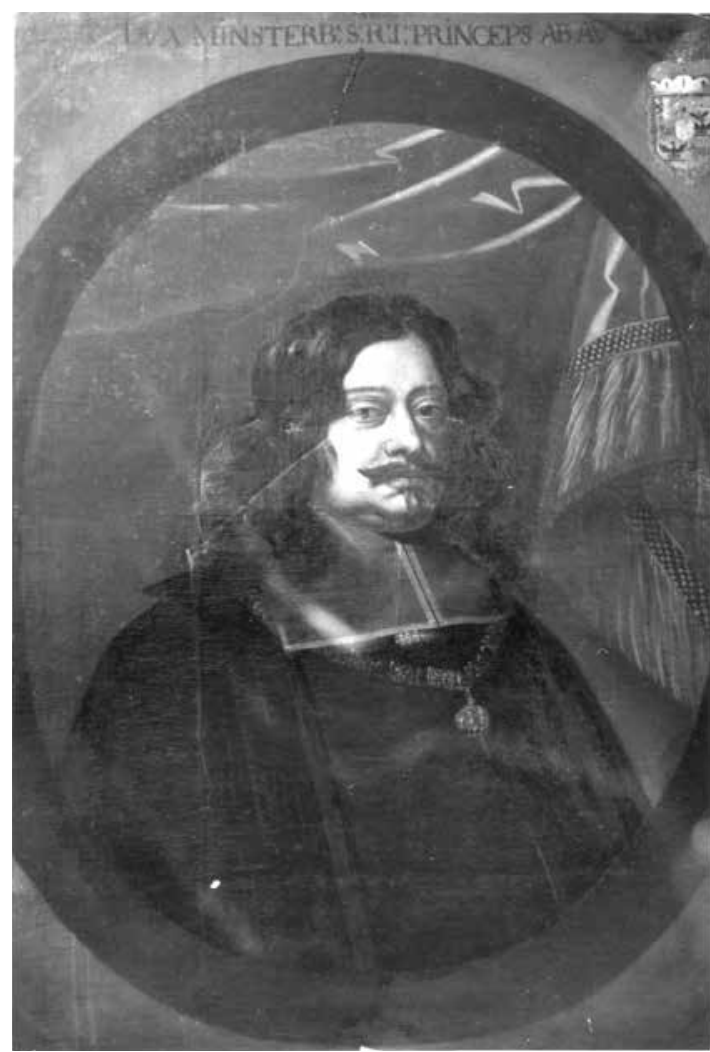

7. Johann Weikhard Auersperg, arhivska fotografija (HR-HDA-1095, kutija 93)

Johann Weikhard Auersperg, archival photograph

bidermajer. Na njezinoj je poleđini sačuvana ceduljica $s$ natpisom: »F. X. Enderle / bürgl. Vergolder / Laimgrube, Gärtnergasse / No 82 in Wien«. Riječ je o pozlataru Franzu Xaveru Enderleu koji je sredinom 19. stoljeća redovito sudjelovao na izložbama austrijskoga primijenjenoga obrta u Beču, izlažući pozlaćene lustere, okvire za slike, okvire za prozore i anđeoske glave, a sudjelovao je i na ukrašavanju i pozlati crkvenoga namještaja. ${ }^{56} \mathrm{Na}$ drugoj takvoj izložbi 1839. godine osvojio je brončanu medalju za "geschmackvolle Zusammenstellung, schöne Färbung, und vollkomene und reine Vergoldung « ${ }^{57}$ a njegov je rad pozitivno ocijenjen i u novinskom osvrtu na treću izložbu u časopisu Der Sammler, Ein Unterhaltungsblatt für alle Stände. ${ }^{58}$ Ostaje nepoznato je li pozlatar Franz Xaver Enderle bio (pre)prodavatelj slike ili je ona u njegovoj radionici samo opremljena ukrasnim okvirom, no oznaka na poleđini slike, jednako kao i okvir u kojem je do danas uramljena, bez dvojbe upućuju na bečko umjetničko tržište sredine 19 . stoljeća.
8. Neznani slikar, Uznesenje Bogorodice, ulje na platnu, $72 \times 44,2 \mathrm{~cm}$, Strossmayerova galerija starih majstora HAZU, inv. br. SG-441 (foto: Fototeka Strossmayerove galerije)

Anonymous painter, The Assumption of the Virgin, oil on canvas, $72 \times$ $44.2 \mathrm{~cm}$, Strossmayer Gallery of Old Masters, HAZU, inv. no. SG-441 


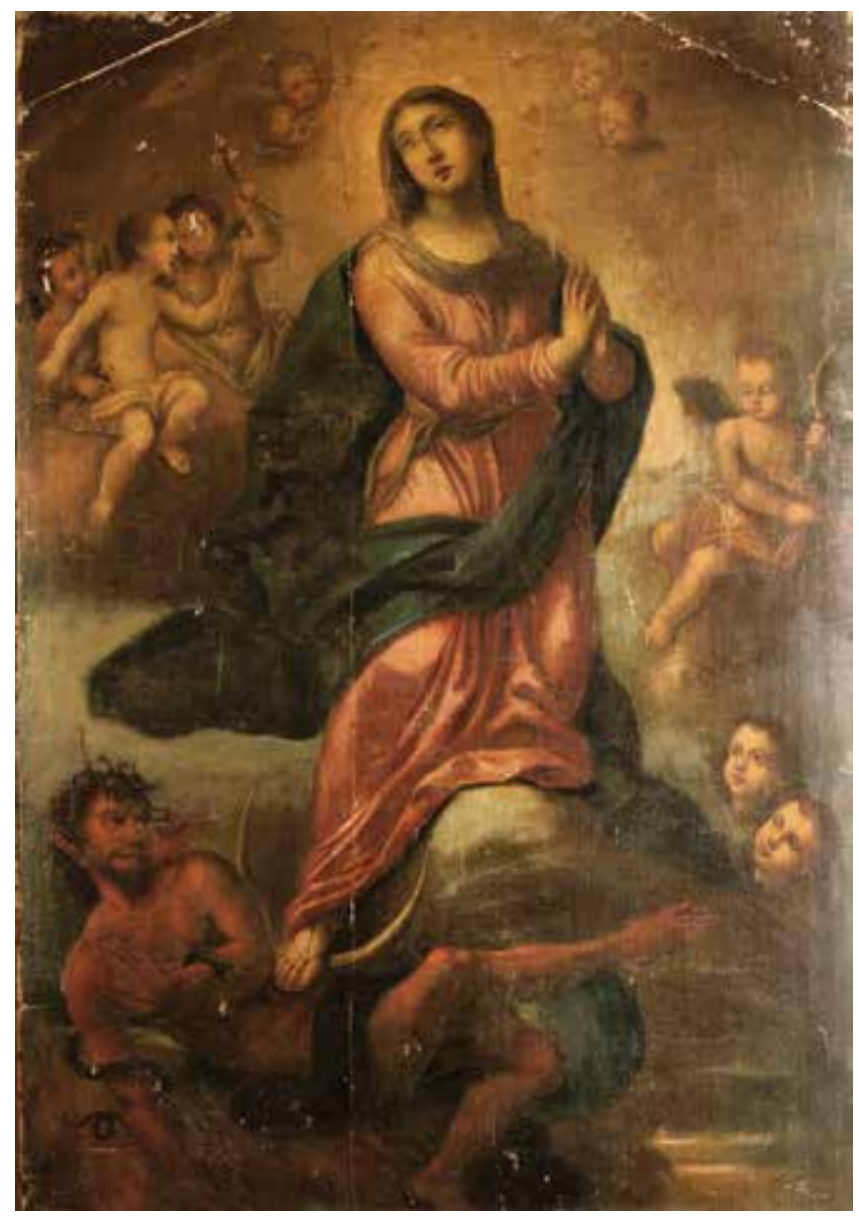

9. Neznani slikar, Bezgrešno začeće, ulje na platnu, $152,5 \times 106,5 \mathrm{~cm}$, Strossmayerova galerija starih majstora HAZU, inv. br. SG-440 (foto: Fototeka Strossmayerove galerije)

Anonymous painter, The Immaculate Conception, oil on canvas, 152.5 $\times 106.5 \mathrm{~cm}$, Strossmayer Gallery of Old Masters, HAZU, inv. no. SG-440

\section{Polaganje u grob Jacopa Palme MI.}

Preko bečkoga umjetničkoga tržišta do naših je krajeva, a potom u Strossmayerovu galeriju, dospjela i slika Jacopa Palme Mlađega Polaganje u grob (sl. 10). Poticaj za današnji smještaj slike u Strossmayerovu galeriju dao je Grgo Gamulin, ukratko iznoseći njezinu povijest i razmatrajući mogućnosti njezine muzealizacije u dopisu koji je uputio Savjetu za kulturu i nauku NR Hrvatske 1957. godine: »U prostorijama Biskupije u Rijeci nalazi se u pohrani slika Palme Mlađega, Polaganje u grob. Slika je bila vlasništvo jednog Jevrejina, koji je, znajući za sudbinu koja ga čeka, za vrijeme rata, predao sliku na čuvanje Biskupu riječkom. Taj nekadašnji vlasnik je za vrijeme rata stradao, a nikakvog nasljednika nije ostavio. Mislim da slika treba da dođe u državno vlasništvo i da se mora u tom smislu inicirati postupak. Koliko je meni poznato, Umjetnička galerija u Rijeci nije za tu sliku zainteresirana, a po svojoj vrijednosti i značenju ona spada u Strossmayerovu galeriju JAZU. Ona je jedno od najljepših djela Palme Mlađega, a ima i neke kompetentne ekspertize. No dovoljan je jedan pogled na fotografiju da se

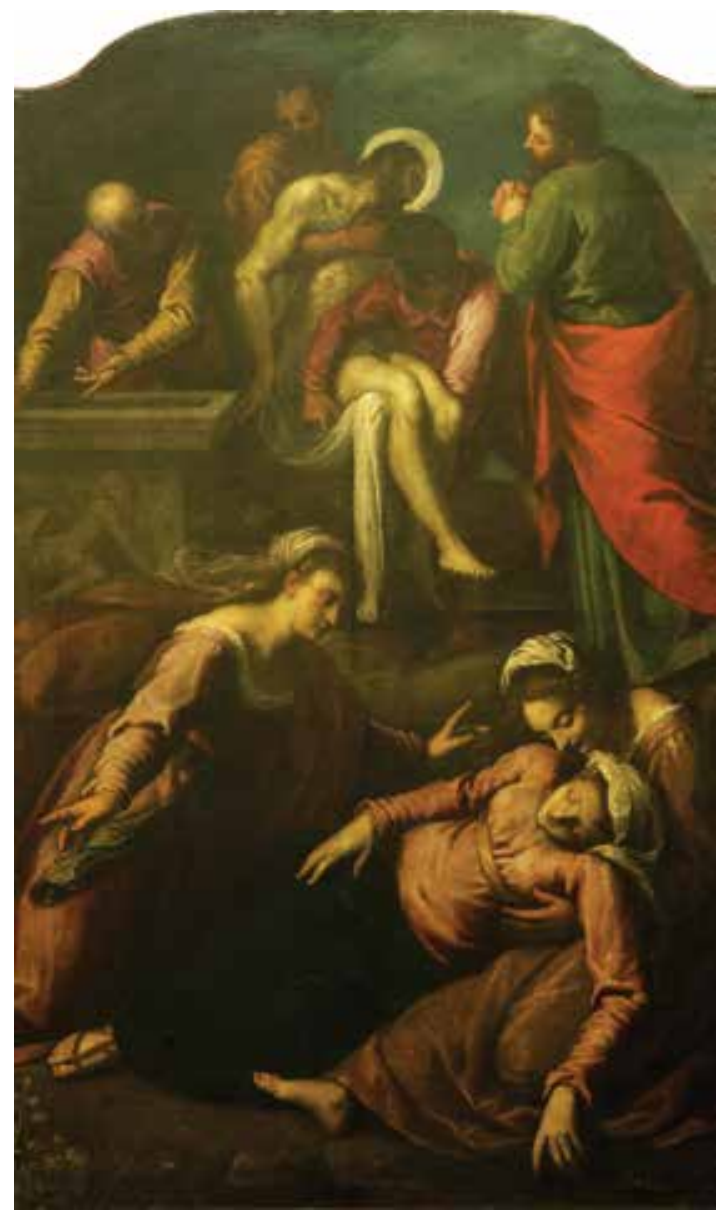

10. Jacopo Palma Ml., Polaganje u grob, ulje na platnu, $230 \times 136 \mathrm{~cm}$, Strossmayerova galerija starih majstora HAZU, inv. br. POH-7 (foto: Fototeka Strossmayerove galerije)

Jacopo Palma the Younger, The Entombment of Christ, oil on canvas, $230 \times 136 \mathrm{~cm}$, Strossmayer Gallery of Old Masters, HAZU, inv. no. $\mathrm{POH}-7$

uvjerimo o njezinoj kvaliteti. Vjerujem da bi se bez poteškoća ovo lijepo djelo moglo dobiti za Jug. Akademiju i učiniti ga pristupačnim javnosti. $\aleph^{59}$

Savjet se po primitku Gamulinova dopisa obratio Konzervatorskom zavodu u Rijeci »s molbom za detaljan izvještaj o predmetu, a napose za izvještaj o pravnoj situaciji u vezi s ovom pohranom « ${ }^{60}$ Uprava JAZU odnosno VII. odjel za likovnu umjetnost požurivao je donošenje odluke Savjeta, raspitujući se »u kojem se stadiju nalazi predmet oko predaje slike« te višekratno ističući »da je Jugoslavenskoj akademiji osobito do toga stalo, da ta vrijedna slika dodje u njezinu Staru galeriju, kamo po svom značaju spada. « ${ }^{61}$ Savjet je pak utvrdio da je "potreban posebni ispitni postupak « ${ }^{62}$ te je čekao rješenje Konzervatorskog odjela u Rijeci, koji je sakupljao saznanja o prijašnjem vlasniku. Razmjena dopisa trajala je nekoliko mjeseci. Iz zapisnika III. sjednice stručnoga savjeta Instituta za likovne umjetnosti od 6. lipnja 1958. godine saznajemo da je Konzervatorski zavod u Rijeci naposljetku donio rješenje kojim je odredio da Biskupski ordinarijat u Rijeci ustupi JAZU-u sliku Palme Mlađega. ${ }^{63}$ Iako je Biskupski ordinarijat protiv toga rješenja podnio žalbu, ${ }^{64}$ slika je 
nedugo potom predana Strossmayerovoj galeriji i upućena u Akademijin Restauratorski zavod, ${ }^{65}$ a potom je izložena na povremenoj izložbi novih akvizicija Galerije ${ }^{66}$ te uvrštena u njezin stalni postav. ${ }^{67}$

Prvi je sliku publicirao Kruno Prijatelj 1955. godine, dok se još nalazila u biskupskoj palači, gdje ju je 'pronašao' Boris Vižintin i na nju upozorio Prijatelja ${ }^{68}$ Nekoliko godina poslije Grgo Gamulin objavljuje studiju o slici u talijanskom časopisu Paragone $e^{69}$ te se potom ona redovito uključuje $u$ opus Palme Mlađega, kao slikarev autografni rad iz kraja 16. stoljeća (1595.-1600.). ${ }^{70}$ Značaj slike u kontekstu slikareva opusa potvrđuju i utvrđene kasnije kopije. ${ }^{71}$

Kao član Odbora za umjetničke galerije, savjetodavnoga tijela koje je osnovao Savjet za kulturu i nauku 1957. godine $» u$ cilju općeg podizanja likovne kulture i unapredjenja likovnog odgoja širokih narodnih slojeva «, ${ }^{72}$ Grgo Gamulin je imao uvid u sve spise o tom predmetu, koji su u arhivskom fondu Savjeta danas samo djelomično sačuvani. U svojoj studiji o slici zabilježio je da je slika bila »u posjedu Edvarda Polaka» te prenio okolnosti pohrane u biskupsku palaču: »Iz drugih dokumenata u spomenutom dosijeu proizlazi, da je vlasnik, ugrožen od nacističkih vlasti u Rijeci, ponudio i predao riječkom biskupu ovu svoju sliku, naravno, s razumljivom namjerom da ova ostane u biskupiji do daljega na čuvanju. (Pismo E. Polaka riječkom biskupu od 18. XI. 1943.) «. ${ }^{73} \mathrm{Ga}-$ mulin je imao uvid i u svjedodžbu Ludwiga Baldassa, koji je sliku ocijenio kao "autentično djelo venecijanskoga slikara Palme Mlađega« i datirao je $\mathrm{u}$ "njegovo prvo umjetničko razdoblje,$^{74}$ a bilo mu je poznato i da su sliku zabilježili Hans i Erika Tietze 1944. godine. ${ }^{75}$

Supružnici Tietze poznavali su sliku iz aukcijskoga kataloga ostavštine Friedricha von Amerlinga iz 1920. godine. ${ }^{76} \mathrm{Tu}$ je dražbu organizirala aukcijska kuća Leo Schidlof's Kunstauktionshaus odnosno Kunst-Auktions-Salon Leo Schidlof u Beču od 1. do 4. prosinca 1920. godine..$^{77}$ Prvoga dana prodavane su slike starih majstora, čiji je katalog sastavio Ludwig von Baldass (kat. br. 1-75). Slika Polaganje u grob navedena je i reproducirana pod brojem 58: "Jacopo Palma Giovine, Grablegung Christi. Unten in der Mitte die ohnmächtige Figur der Maria im Schoße einer heiligen Frau. Vor ihr kniet eine zweite weibliche Gestalt. In der oberen Hälfte des Bildes wird Christus von zwei Männern ins Grab getragen, das links sichtbar wird. Über dem Grab die Figur des Josef von Arymathea, rechts Johannes mit gerungenen Händen. Charakteristische Arbeit dieses Schülers von Tintoretto. Leinwand, $225 \times 136$. " $^{78}$

Riječ je o drugoj po redu prodaji umjetnina iz ostavštine austrijskoga slikara Friedricha von Amerlinga (1803.-1887.), o kojoj najviše saznanja crpimo iz predgovora kataloga aukcijske kuće Dorotheum iz 1916. godine, kada je prodavan veći dio Amerlingove zbirke. ${ }^{79} \mathrm{Zbirka}$ umjetnina iz različitih europskih umjetničkih škola i širokoga vremenskog raspona pripala je nakon Amerlingove smrti 1887. godine njegovoj drugoj ženi, poslije grofici Marie Hoyos, koja je prije smrti 1914. godine ovlastila Bečki Künstlergenossenschaft svojim nasljednikom, s naputkom o osnivanju Friedrich und Marie Amerling-Fonds za potporu potrebitih umjetnika. ${ }^{80}$ Usprkos velikom broju umjetnina u zbirci, Amerlingova sakupljačka djelatnost još nije postala predmetom istraživanja. ${ }^{81}$ Nešto više pažnje zadobio je dvorac Gumpendorf u predgrađu Beča, koji je Amerling 1858. godine na jednom od svojih »Antiquitätenjagd « kupio za smještaj svoje rastuće zbirke. ${ }^{82}$ Osim sačuvanih fotografija interijera koje svjedoče o raskoši zbirke, ${ }^{83}$ ostalo je zabilježeno svega par anegdota koje prikazuju Amerlinga kao snalažljivoga i odvažnog sakupljača koji je spretno nabavljao umjetnine ne samo putem profesionalnih posrednika, nego i izravno od vlasnika. Tako je, primjerice, pod geslom eine Frage ist freu predložio svećeniku Theobaldu Steindlu iz samostana u Klosterneuburgu razmjenu umjetničkih predmeta ${ }^{84} \mathrm{Je}$ li na isti način, izravnim kontaktom $\mathrm{s}$ vlasnikom odnosno imateljem, Amerling došao i do oltarne slike Palme Mlađega, ili ju je pak nabavio preko posrednika koji su dopremali talijanske umjetnine na bečko odnosno austrijsko umjetničko tržište, ostaje nepoznato.

Nije moguće utvrditi niti je li sliku Polaganje u grob njezin posljednji vlasnik, koji ju je 1943. godine pohranio u riječkoj biskupiji, kupio izravno na dražbi Amerlingove zbirke 1920. godine ili ju je pak nabavio poslije i pod kojim okolnostima. Eduard Polak zabilježen je kao vlasnik tvornice Ljuštionice riže u Rijeci 1929. godine kada je dao zahtjev za useljenje tvornice u već postojeći objekt likvidirane Kožare BakarčićSimonić (Ružićeva ulica 29), tražeći građevinsku dozvolu za adaptacijske intervencije. ${ }^{85}$ Istodobno je tražio dopuštenje za upotrebu strojeva nužnih za rad Ljuštionice. Uvozeći sirovinu iz Italije, Egipta, Indije i Amerike, te proizvodeći sve vrste riže, osigurao je uspješan rad Ljuštionice čiji je godišnji kapacitet od oko 2400 vagona dokumentiran 1938. godine ${ }^{86}$ no detaljniji se biografski podaci o vlasniku riječke Ljuštionice ne spominju.

Istraživanjem provedenim u tršćanskim arhivima bilo je moguće iznaći još neke podatke. U Archivio di Stato di Trieste čuvaju se dokumenti o nepokretnoj imovini Edouarda Pollaka (fu Carlo) iz Rijeke, via Grossich $1{ }^{87}$ no u njima nema nikakvih podataka o pokretninama. Međutim, u arhivu Sopraintendenza Polo Museale Trieste (tzv. Fondo Istria) čuva se pismo kojim Riccardo Gigante, tadašnji počasni konzervator za područje Rijeke, nadležnom konzervatorskom uredu u Trstu u ožujku 1944. godine prenosi zahvalnost riječkoga biskupa "per l'azione svolta a impedire l'asportazione della Deposizione di Palma di Vecchio di proprieta Pollak, la quale e rimasta in consegna alla Curia vescovile di Fiume «. ${ }^{88}$ Nedugo potom, kako je prenio Gamulin, njemački savjetnik (Berater) za Rijeku »dr. Karl Pachneck obavijestio je biskupa, da mu vrhovni njemački komesar ostavlja ovo Palmino djelo 'na dar.' (Pismo dr. Karla Pachnecka riječkom biskupu od 28. VIII. 1944.) «. ${ }^{89}$ Naposljetku, Edoardo Pollak evidentiran je u bazi podataka talijanskih žrtava holokausta 1943. - 1945., kao sin Carla Pollaka, rođen u Osijeku 8. studenoga 1876. godine, uhićen u Rijeci, stradao u nacističkom logoru Risiera di San Sabba u Trstu. ${ }^{90}$

Istraživanja u tršćanskim i riječkim arhivskim fondovima nastavljaju se s ciljem iznalaženja preciznijih podataka o sudbini Edouarda Pollaka te njegove i imovine ostalih izvlaštenih osoba na istome području. Za sada možemo tek 
pretpostaviti da je posljednji vlasnik slike Polaganje u grob zasigurno posjedovao određeni broj umjetnina, a možda i definiranu umjetničku zbirku, jer je bio vlasnik oltarne pale velikih dimenzija i nesumnjive umjetničke kvalitete. Takvu je sliku bilo nemoguće iznijeti izvan kontroliranog područja bez valjanih administrativnih dozvola, pa je tijekom ratnih zbivanja ostala sačuvana u Rijeci pohranom u biskupskom posjedu.

\section{$* * *$}

Tih nekoliko slika koje su dospjele u zbirni fond Strossmayerove galerije temeljem odluka saveznih i republičkih jugoslavenskih državnih tijela, tek je mali dio gotovo nepreglednoga pokretnog kulturnog nasljeđa nekada $u$ privatnom vlasništvu, koje je nakon turbulentnih ratnih i poratnih zbivanja postalo 'općenarodnom imovinom', odnosno prešlo u državno vlasništvo. Savjet za kulturu i nauku 1958. godine tražio je od nadležnoga državnog tijela uputu »kako da se postupi s umjetninama (...) koje su vlasnici napustili u toku okupacije, a koje su pohranjeni u muzejima, galerijama i drugim ustanovama«, te je Državni sekretarijat za pravosudnu upravu NR Hrvatske 9. travnja 1958. godine

\section{Bilješke}

* Istraživanje za ovaj rad provedeno je u okviru HERA projekta 15.080 TransCultAA (Transfer of Cultural Objects in the Alpe Adria Region in the 20th Century, http://www.transcultaa.eu). Projekt je financiran sredstvima programa Europske unije Obzor 2020 za istraživanje i inovacije, u okviru Ugovora o dodjeli sredstava br. 649307.

1

ANA HOLJEVAC TUKOVIĆ, Društveno-gospodarske reforme 1950-1952 i njihov odraz na upravu Narodne Republike Hrvatske, u: Arhivski vjesnik, 46/1 (2004.), 131-146.

2

Savjet za nauku i kulturu FNRJ sljednik je Ministarstva za nauku i kulturu Vlade FNRJ. Isto, 138-139. Ministarstvo za nauku i kulturu Vlade FNRJ formirano je 11. prosinca 1948. godine objedinjavanjem Komiteta za kulturu i umjetnost i Komiteta za škole i nauku. IVAN HOFMAN, Komitet za kulturu i umetnost pri Vladi FNRJ (Ustanova i njena arhivska građa), u: Časopis Arhiva Jugoslavije, 2 (2001.), 43-48.

3

EGON KRALJEVIĆ, Sumarni inventarni fond, Savjet za prosvjetu nauku i kulturu (1951.-1956.), Zagreb, Hrvatski državni arhiv, 2005.

4

MARINA SELNIK, Sumarni inventar za fond, Savjet za kulturu i nauku NRH (1956.-1961.), Zagreb, Hrvatski državni arhiv, s. d. donio priopćenje: »Prema tome, ukoliko bliski srodnici vlasnika napuštenih stvari koji je umro ili nestao nisu na vrijeme pokrenuli ostavinski postupak, postale su ove stvari općenarodna imovina i više se zahtjev za vraćanje tih stvari od strane nasljednika ne bi mogao sa uspjehom postaviti. Nema stoga zaprijeke da muzeji i druge ustanove kod kojih su pohranjene umjetnine, koje su vlasnici napustili u toku okupacije, uvede u svoje inventarske knjige, jer su te stvari postale općenarodnom imovinom. ${ }^{91}$

$\mathrm{Na}$ taj način regulirano je pitanje pravnoga statusa velikoga broja umjetničkih predmeta u hrvatskim muzejima. Istraživanje njihove sudbine prije i tijekom poslijeratne muzealizacije izazovan je, no nužan element u obuhvatnoj znanstvenoj i stručnoj obradi nacionalne kulturne baštine. Novim izazovima bavljenja promjenama vlasništva, koji uključuju i različite oblike i mehanizme izvlaštenja, među prvima je pozvana odgovoriti upravo povijest umjetnosti kao disciplina koja je u posljednjih nekoliko desetljeća razvila različite metodološke modele bavljenja fenomenom vlasništva, bilo u kontekstu naručitelja i prvotne namjene djela ili u kontekstu umjetničkoga tržišta i povijesti kolekcionarstva, ostvarivši pritom velike pomake na području integriranja istraživanja provenijencije umjetnina u standardnu povijesnoumjetničku analizu.

5

Način: Salvatore Rosa, Fantastični krajolik, ulje na platnu, $80 \times$ $120 \mathrm{~cm}$, Strossmayerova galerija starih majstora HAZU, inv. br. SG-474. Niz dokumenata o tom otkupu sačuvan je $u$ arhivskom fondu Savjeta za kulturu i nauku, Hrvatski državni arhiv (dalje: HR-HDA)-1599, kutija 98.

6

Andrija Medulić, Izak blagoslivlja Jakova, ulje na platnu, 29,7 × $104,5 \mathrm{~cm}$, Strossmayerova galerija starih majstora HAZU, inv. br. SG-476. Nadopuna teksta za izvještaj o radu u 1961. god., Strossmayerova galerija Zavodu za likovne umjetnosti, Zagreb, 19. prosinca 1961. godine. Arhiv Strossmayerove galerije (dalje: Arhiv SG), 1961. i 1962.

7

Oton Gliha, Crne smokve, ulje na platnu, $40 \times 60 \mathrm{~cm}$, Strossmayerova galerija starih majstora HAZU, inv. br. SG-608.

8

Dar Z. Balokoviću, ustupanje iz inventara Savjeta, 10. travnja 1954. HR-HDA-1095, kutija 92.

9

JOYCE BORDEN BALOKOVIĆ, Singing wings. An Autobiographical Biography of Zlatko Baloković, Concert Violinist And Citizen of The World, s. 1., 1973.

10 ĐURO VANĐURA, Umjetnine iz donacije Joyce i Zlatko Baloković, katalog izložbe, (ur.) Vinko Zlamalik, Zagreb, 1989. 
11

Sekvestracija, odnosno stavljanje imovine pod državnu upravu, jedna je od eksproprijacijskih mjera kojima se provodio preustroj ekonomskoga poretka u poslijeratnoj Jugoslaviji. O tome vidi: TOMISLAV ANIĆ, Normativni okvir podržavljenja imovine u Hrvatskoj/Jugoslaviji 1944.-1946., u: Časopis za suvremenu povijest, 39/1 (2007.), 25-62.

12 Istraženi su i analizirani dokumenti koji se čuvaju u sljedećim arhivskim fondovima: HR-HDA-1095, Savjet za prosvjetu, nauku i kulturu; HR-HDA-1599, Savjet za kulturu i nauku; HR-HDA-313, Zemaljska uprava narodnih dobara; Arhiv SG; Arhiv Hrvatske akademije znanosti i umjetnosti (dalje Arhiv HAZU), The National Archives and Records Administration (dalje: NARA), Archivio di Stato di Trieste (dalje: AST), Arhiv pri Soprintendenza Polo Museale Trieste (dalje: SPMT).

13

Potvrda od 13. studenoga 1948. Arhiv HAZU, kutija 89, 1948.

14

Potvrda od 10. studenoga 1952. Arhiv SG, kutija 5 (1944.-1952.), 1952.

15

LJUBO BABIĆ - ZDENKO ŠENOA, Katalog Galerije slika Jugoslavenske akademije znanosti i umjetnosti, Zagreb, 1950., 78, kat. br. 175.

16

VINKO ZLAMALIK, Strossmayerova galerija starih majstora Jugoslavenske akademije znanosti i umjetnosti, Zagreb, 1967., 282, kat. br. 146 .

17

Sto godina Strossmayerove galerije 1884.-1984. Izložba u povodu stote obljetnice otvorenja Strossmayerove galerije starih majstora Jugoslavenske akademije znanosti i umjetnosti, katalog izložbe, (ur.) Vinko Zlamalik, Zagreb, 1984., 100, kat. br. 248; ĐURO VANĐURA, Nizozemske slikarske škole u Strossmayerovoj galeriji starih majstora Jugoslavenske akademije znanosti i umjetnosti, Zagreb, 1988., 138-139.

18

IVY KUGLI, Referat o suradnji Galerije Jugoslavenske akademije s Nacionalnim centrom za proučavanje 'Flamanskih primitivaca' u Bruxellesu, u: Bulletin Instituta za likovne umjetnosti JAZU, 1/6 (1958.), 47-50.

\section{9}

ABRAHAM BREDIUS, Pieter Jansz. Quast, u: Oud Holland, 20 (1902.), 65-82.

20

JAAP LEEUWENBERG, Beeldhouwwerk van de schilder Pieter Quast, u: Bulletin van het Rijksmuseum, 14/2 (1966.), 60-64; JURIJ I. KUZNECOV, Pieter Quast copied Savery's 'Naar het leven' drawings, u: Album amicorum J. G. van Gelder, (ur.) J. Bruyn, J. A. Emmens, Den Haag, 1973., 215-218; DIEUWKE DE HOOP SCHEFFER, Een serie bedelaars door Pieter Quast: 'T is al Verwart-Gaeren', u: The Rijksmuseum bulletin, 22/4 (1974.), 166-172; BARBARA ANN STANTON HIRST, Pieter Quast and the theatre, u: Oud Holland, 96 (1982.), 213-237; ZOLTÁN KOVÁCS, The witty Pieter Quast, the works of an Amsterdam master in Hungary then and now, u: Bulletin du Musée Hongrois des Beaux-Arts, 104 (2006.), 101-128, 209-224.

21

Staatliche Kunstgutbergung, Salzbergbau Alt-Aussee, Oberösterreich, Salzberg, 18. lipnja 1946. NARA M1926. Records of the Reparations and Restitutions Branch of the U.S. Allied Commission for Austria (USACA) Section, 1945-1950. Dostupno na: https://www.fold3.com/image/300250625 (26. 6. 2017.).

22

Yugoslav property in Altaussee mine, 1. svibnja 1946. USACA Section, Reparations and Restitution Branch, 1. svibnja 1946. Isto. Dostupno na: https://www.fold3.com/image/274415299; https:// www.fold3.com/image/274415303 (26. 6. 2017.).

23

Sonderliste G. Isto. Dostupno na: https://www.fold3.com/image/300251053 (26. 6. 2017.).

24

Ölgemälde, Aquarelle, Miniaturen, Zeichnungen, Graphik, Plastik, Einrichtungsgegenstände und Uhren, Textilien, Gold-, Silber- und andere Metallarbeiten, Porzellan, Fayence, Glas, Verschiedenes, Ostasiatika, Waffen, Ausgrabungen. Dorotheum, Beč, 3.-5. listopada 1944., 7, kat. br. 85, Tafel 13 .

25

STEFAN AUGUST LÜTGENAU - ALEXANDER SCHRÖCK - SONJA NIEDERACHER, Zwischen Staat und Wirtschaft, das Dorotheum im Nationalsozialismus, Beč et al., 2006.; FELICITAS THURN-VALSASSINA, Provenienzforschung im Dorotheum, $\mathrm{u}$ : ...wesentlich mehr Fälle als angenommen, 10 Jahre Kommission für Provenienzforschung, (ur.) Gabriele Anderl, Christoph Bazil, Eva Blimlinger, Beč, Köln, Weimar, 2009., 253-262; SONJA NIEDERACHER - STEFAN AUGUST LÜTGENAU, The Dorotheum as a Case Study of Austria after Fascism: Narratives of Opfermythos and Wiederaufbau after 1945, u: After Fascism: European Case Studies in Politics, Society, and Identity since 1945, (ur.) Matthew Paul Berg, Maria Mesner, Beč, 2009., 131-152.

26

Vidi ASTRID BÄHR, German Sales 1930-1945, Bibliographie der Auktionskataloge aus Deutschland, Österreich und der Schweiz, Berlin, 2013., 571-572. Dostupno na: http://archiv.ub.uni-heidelberg.de/artdok/volltexte/2013/2251.

27

Vidi KATHRIN ISELT, Sonderbeauftragter des Führers. Der Kunsthistoriker und Museumsmann Hermann Voss (1884-1969), Köln, Weimar, Wien, 2010., 304-305.

28

»November 1919. Pieter Quast. 99) Dans l'auberge. Dans un intérieur sont plusieurs paysans, dont deux jouent aux cartes. L'un, à gauche, debout, l'altre à droite, assis. Il montre ses cartes avec les quatre as. Il porte un bonnet rouge, un costume violet avec des manches bleues, un pantalon jaune. Au millieu un homme avec un pot à bière à la main, un autre regarde; deux autres sont assis à gauche et au second plan. Un septième regarde par la porte. Bois haut 32.5 cent. larg 43.5 cent. Tent. Goudstikker, Den Haag November 1919.« Hofstede de Grootfiches, Quast, Pieter Jansz., baknummer 207, fichenummer 1419009. Dostupno na: https:// rkd.nl/nl/explore/excerpts/415797 (15. 5. 2017.).

29

Vidi CHARLOTTE WIETHOFF, De kunsthandelaar Jacques Goudstikker (1897-1940) en zijn betekenis voor het verzamelen van vroege Italiaanse kunst in Nederland, u: Nederlands kunsthistorisch jaarboek, 32 (1981.), 249-276.

30

PIETER DEN HOLLANDER - MELISSA MÜLLER, Jacques Goudstikker (1897-1940), Amsterdam, u: Verlorene Bilder, verlorene Leben, Jüdische Sammler und was aus ihren Kunstwerken wurde, (ur.) Melissa Müller, Monika Tatzkow, München, 2014., 214-229, 218. 
31

PETER C. SUTTON, Reclaimed: Paintings from the Collection of Jacques Goudstikker, New Haven, 2008.

32

Catalogue de la collection Goudstikker, d'Amsterdam, exposée dans les localités du Schilderkundig Genootschap 'Pulchri Studio', la Haye, novembre 1919, katalog izložbe, Haarlem, 1919., kat. br. 99.

\section{3}

»Pieter Quast 1605/1606 Amsterdam 1647. In een herberg zijn kaartspelende boeren om een bankje gegroepeerd. Zij zijn in druk gesprek. In het midden een man, die een pot bier opheeft. De frissche kleureen der kleeding breken de bruine toon, waarin het stuk geschilderd is. Paneel: Hoog 32 1/2 c.M., Brees 43 1/2 c.M." Catalogus van de Collectie Goudstikker, katalog izložbe, Rotterdam, 1919., kat. br. 75 .

\section{4}

Raspodjela slika pohranjenih u Hrv. zemaljskoj banci d. d. u likvidaciji, 26. studenoga 1954. Muzejska dokumentacija SG, dokumentacija o slici inv. br. SG-440; Arhiv SG, registrator 1 (1953.-1956.), 1954.

\section{5}

Komisijski zapisnik, Donja Dubrava, 1. ožujka 1946. HRHDA-313, kutija 401, 69 Borka, trgovina drvom Donja Dubrava, Eugen Kaufmann i Đuro Gruber.

\section{6}

DRAGUTIN FELETAR - HRVOJE PETRIĆ, Donja Dubrava - središte splavarstva na rijeci Dravi, u: Ekonomska i ekohistorija, Časopis za gospodarsku povijest i povijest okoliša, 3 (2007.), 156-173; HRVOJE PETRIĆ, Rijeka Drava i Međimursko selo u novome vijeku - primjer Donje Dubrave (18.-20. stoljeće), u: Podravina, 10/20 (2011.), 38-56, 51-56.

37

HRVOJE PETRIĆ (bilj. 36), 56.

38

VLADIMIR KALŠAN, Međimurje u Drugom svjetskom ratu, Čakovec, 2015.

39

Dodatak k zapisniku sekvestrirane imovine Eugena Kaufmanna. HR-HDA-313, kutija 401, 69 Borka, trgovina drvom Donja Dubrava, Eugen Kaufmann i Đuro Gruber.

40

Popisni list, Donja Dubrava, 1. ožujka 1946. Isto.

41

Dodatak k zapisniku sekvestrirane imovine Eugena Kaufmanna. Isto.

42

VLADIMIR KALŠAN (bilj. 38), 67.

43

Komisijski zapisnik, Donja Dubrava, 1. ožujka 1946. HRHDA-313, kutija 401, 69 Borka, trgovina drvom Donja Dubrava, Eugen Kaufmann i Đuro Gruber.

44

Savjet za prosvjetu, nauku i kulturu Hrvatskoj zemaljskoj banci d. d. u likvidaciji, Zagreb, 12. svibnja 1954. HR-HDA-1095, kutija 92.

45

Savjet za prosvjetu, nauku i kulturu Konzervatorskom zavodu, Zagreb, 12. svibnja 1954. Isto.
46

Konzervatorski zavod Savjetu za prosvjetu, nauku i kulturu, Zagreb, 9. rujna 1954. HR-HDA-1095, kutija 93.

47

Savjet za prosvjetu, nauku i kulturu Konzervatorskom zavodu, Zagreb, 16. studenoga 1954. Isto.

48

Slika je predana 16. lipnja 1956. godine Gliptoteci, u tzv. galeriju kopija, gdje je evidentirana pod brojem Ga.K-83., no na sljedećim revizijama zbirnog fonda Gliptoteke nije pronađena. Na podacima zahvaljujemo Magdaleni Getaldić, višoj dokumentaristici Gliptoteke HAZU.

49

Obje su slike u galerijskom inventaru određene tek kao djelo neznanog slikara 19. stoljeća. Dosad nisu objavljivane niti pobliže analizirane. U oba je slučaja riječ o kasnim preradama ustaljenih ikonografskih obrazaca koje bi budućim istraživanjima trebalo precizirati.

50

Slovenski (?) slikar 17. stoljeća, Johann Andre Auersperg, ulje na platnu, $97 \times 68 \mathrm{~cm}$, Hrvatski povijesni muzej, inv. br. HPM/PMH8704; Slovenski slikar 17. stoljeća, Johann Weikhard Auersperg, ulje na platnu, $124 \times 84,5 \mathrm{~cm}$, Hrvatski povijesni muzej, inv. br HPM/PMH-8705. Na podacima zahvaljujemo dr. sc. Marini Bregovac Pisk, muzejskoj savjetnici Hrvatskog povijesnog muzeja.

51

MATEJ KLEMENČIČ - UROŠ LUBEJ - BARBARA MUROVEC, The counts of Auersperg Portrait Gallery from Gornja Radgona and the question of its author(s), izlaganje na međunarodno konferenciji Flemish and Dutch painters in Central Europe and northern Italy in the late 17th century, Ljubljana, 20.-21. listopada 2005. Dostupno na: https://www.codart.nl/guide/exhibitions/flemish-and-dutch-painters-in-central-europe-and-northern-italyin-the-late-17th-century-almanach-and-the-painting-of-the-second-half-of-the-17th-century-in-carniola/ (27. lipnja 2017.). Za raniju pretpostavku o drugačijoj provenijenciji vidi: MARIJANA SCHNEIDER, Portreti 16.-18. stoljeća, Povijesni muzej Hrvatske, Zagreb, 1982., 58-59, kat. br. 50 i 51.

52

France Stele, Gornja Radgona - Grad, fotografija interijera. Ministarstvo za kulturo, Direktorat za kulturno dediščino, INDOK center (fototeka - steklene plošče), Slovenija. Dostupno na: http:// www.europeana.eu/portal/en/record/08520/MK_Steklo_f00000_ n10613s_b_jpg.html (27.6. 2017.).

53

Vrijednosti koje se nalaze u pologu Hrvatske zemaljske banke d. d. u lik., 28. rujna 1946.; Hrvatska zemaljska banka d. d. u likvidaciji Odjelu za narodnu imovinu Predsjedništva vlade NRH, 21. listopada 1946. HR-HDA-283, Min. Financ. NRH (u sređivanju), bivše kut. 443-449 PV NRH, Sefovi.

54

Nije poznato je li Eugen Kaufmann slike izravno kupio na aukciji ili ih je kupio naknadno od nekog hrvatskog staretinara, odnosno preprodavača umjetnina koji su između dvaju ratova aktivno kupovali na aukcijama u Dravskoj banovini.

55

Sonderauktion im Schloss Gornja Radgona von Einrichtungs Gegenständen aus dem ehemals Gräfllich Chorinsky'schen Familienbesitze. Montag, den 28. Oktober 1929 und Dienstag, den 29. Oktober 1929. Na pomoći pri istraživanju zahvaljujemo dr. sc. Renati Komić Marn s Instituta France Stele u Ljubljani. 
56

Vidi Bericht über die erste allgemeine österreichische Gewerbsproducten-Ausstellung im Jahre 1835., Beč, 1836., 316; Bericht über die zweite allgemeine österreichische Gewerbs-Producten-Ausstellung im Jahre 1839., Beč, 1840., 392; Bericht über die dritte allgemeine österreichische Gewerbe Ausstellung im Jahre 1845., Wien, 1846., 701; DECHANT KARL BOCK, Zur Geschichte der Kirche in Bernhardsthal, u: Kirchenkunst, österreichische Zeitschrift für Pflege religiöser Kunst, 3 (1931). Dostupno na: http://heimat.lima-city. de/Bern/kirche/Geschichte/bock_kirchengesch.htm (7.4. 2107.).

57

Bericht über die zweite österreichische Gewerbs-Producten-Ausstellung... (bilj. 56), 392.

\section{8}

Vidi Industrie-Austellung (Fortsetzung), u: Der Sammler, Ein Unterhaltungsblatt für alle Stände, 115 (21. 7. 1845.), 453.

\section{9}

Grgo Gamulin Savjetu za kulturu i nauku NR Hrvatske, Zagreb, 14. studenoga 1957. HR-HDA-1599, kutija 97.

60

Savjet za kulturu i nauku JAZU-u, Zagreb, 10. prosinca 1957. Pismohrana HAZU, 1958., 300-600.

61

Odjel za likovne umjetnosti upravi JAZU, Zagreb, 6. ožujka 1958.; Andrija Štampar Savjetu za kulturu i nauku, Zagreb, 8. 3. 1958. Isto.

62

Savjet za kulturu i nauku JAZU, 21. 4. 1958. Isto.

63

Zapisnik III. redovite sjednice stručnog savjeta Instituta za likovne umjetnosti JAZU, 6. lipnja 1958. Pismohrana HAZU, 1958., 160-300.

64

Isto.

65

Obavijest o preuzimanju slike Palme Mlađeg. Arhiv SG, 1958.1960.

66

Nove nabave, restaurirane i konzervirane umjetnine i pojedina djela iz spremišta Stare galerije, katalog izložbe, Zagreb, 1958., kat. br. 5.

67

VINKO ZLAMALIK, Strossmayerova galerija starih majstora Jugoslavenske akademije znanosti i umjetnosti, Zagreb, 1982., 184-185.

68

KRUNO PRIJATELJ, Palmino polaganje u grob u Rijeci, u: Riječka revija, 5-6 (1955.), 256.

69

GRGO GAMULIN, Due dipinti di Palma il Giovane, u: Paragone, 9/115 (1959.), 50-53.

70

STEFANIA MASON RINALDI, Palma il Giovane, l'opera completa, Milano, 1984., 151, br. 615.

71

Kopija po: Jacopo Palma Ml., Polaganje u grob, ulje na platnu, $137,1 \times 100,3 \mathrm{~cm}$, Barnard Castle, Newgate, Muzej Bowes, Isto, 151; Kopija po: Jacopo Palma Ml., Polaganje u grob, ulje na platnu,
$216 \times 141 \mathrm{~cm}$, Ženeva, Muzej umjetnosti i povijesti, MAURO NATALE, Peintures italiennes du XIV ${ }^{\mathrm{e}}$ au XVIII ${ }^{\mathrm{e}}$ siècle, Genève, 1979., 96-97, br. 127.

72

Savjet za kulturu i nauku osnovao je 15. srpnja 1957. godine Odbor za umjetničke galerije za podizanje likovne kulture, a potom su u studenom imenovani njegovi članovi. HR-HDA-1599, kutija 25.

73

GRGO GAMULIN, Dvije slike Palme Mlađega, u: Stari majstori u Jugoslaviji I., Zagreb, 1961., 131-135, 131.

74

Isto, 131, bilj. 1.

75

Isto, 131, bilj. 4 i 5; Vidi: HANS TIETZE - ERIKA TIETZE CONRAT, The drawings of the Venetian painters in the 15th and 16th centuries, New York, 1944., 200, br. 836.

76

HANS TIETZE - ERIKA TIETZE CONRAT (bilj. 75).

77

Nachlass Friedrich v. Amerling und anderer Besitz: alte u. moderne Gemälde, Aquarelle, Miniaturen, Waffen, Silber, Vitrinenobjekte, Porzellan, Bronzen, Kunstmobiliar, Textilien, Teppiche. Wien, Leo Schidlof's Kunstauktionshaus, 1.-4. 12. 1920.

78

Isto, kat. br. 58.

79

FRIEDRICH STERN, Friedrich von Amerling, u: Nachlaß Friedrich von Amerling (Stiftung für die Genossenschaft der bildenden Künstler Wiens), Versteigerung, Dorotheum, Wien, 3.-6. 5. 1916., VII-X.

80

Isto.

81

I novija literatura koncentrira se uglavnom na Amerlinga kao slikara. Vidi Friedrich von Amerling, 1803-1887, katalog izložbe, (ur.) Sabine Grabner, Leipzig, 2003.

82

LUDWIG AUGUST FRANKL, Friedrich von Amerling, ein Lebensbild, Beč, 1889., 88.

83

Friedrich von Amerling (bilj. 81).

84

Friedrich von Amerling Theobaldu Steindlu u Klosterneuburgu, Beč, 30. lipnja 1863. Publicirano u: GÜNTHER PROBSZT, Friedrich von Amerlings Tagebuch und Briefe, Beč, 1928., 28.

85

EMA ANIČIĆ, Riječka industrijska priča, Rijeka, 2014., 122-125.

86

Almanah grada Sušaka, 1938. Isto.

87

Pollak, Edoardo fu Carlo (Fiume). AST, UTE Diritti immobiliari di proprietari di razza ebraica (1939-1944), busta 35, fascicolo 625 , numero incarico 555

88

Riccardo Gigante alla Soprintendenza ai Monumenti e alle Gallerie della Venezia Giulia e del Friuli, Rijeka, 19. ožujka 1944. 
SPMT, Istria Quarnero Dalmazia, busta 44, fasciolo 2808 (Aff. Gen. Accentramento opere d'arte di proprieta ebraica).

89 GRGO GAMULIN (bilj. 69), 131.

90

Shoah Victims names, Centro di Documentazione Ebraica Contemporanea. Dostupno na: http://digital-library.cdec.it/cdec- web/persone/detail/person-6118/pollak-edoardo.html (27. 6. 2017.).

91

Postupanje s pohranjenim spomenicima kulture, koje su vlasnici napustili tijekom okupacije, Savjet za kulturu i nauku svim Narodnim odborima kotara, svim Konzervatorskim zavodima, Jugoslavenskoj akademiji znanosti i umjetnosti, Sveučilišnoj knjižnici, Državnom arhivu, 21. travnja 1958. HR-HDA-1599, kutija 97.

\section{Summary}

Iva Pasini Tržec - Ljerka Dulibić

\section{On the Provenance of Several Paintings Coming to the Strossmayer Gallery by the State Orders of FNRJ (1948-1958)}

Based on decisions of the Comissions for (Education), Sciences and Art (1951-1956-1961) of the Federal People's Republic of Yugoslavia (FNRJ), several artworks joined the holdings/collection of the Strossmayer Gallery of Old Masters in the period between 1948 and 1958. In 1948, it was the painting Card Players by Pieter Jansz. Quast (by decision of the Culture and Art Committee in Belgrade i.e. the later FNRJ Commission for Science and Culture); in 1954 paintings The Assumption of the Virgin, The Immaculate Conception, and Our Lady of Mercy (by decision of the Commission for Education, Science and Culture); and in 1958 The Entombment of Christ by Jacopo Palma the Younger (by the decision of the Commission for Art and Science). These artworks had formerly been part of private collections, mostly Jewish, sequestered during the war or afterwards.

Having analysed a wide range of archival sources relevant for the transfer of artworks shortly before, during, and after World War II, their former owners and/or some of the circumstances of the change of ownership have been identified. It has been established with considerable probability that the Card Players by Pieter Jansz. Quast was in 1919 owned by Jacques Goudstikker, the most prominent Dutch art dealer between the two World Wars, who was forced to flee the country because of his Jewish origins and was killed in an accident in 1940. In 1944, the painting is documented on sale by the Viennese auction house Dorotheum, which operated during World War II under the Nazi administration, and in 1946 it is listed as a former "property of Yugoslavia" among the paintings that Dorotheum deposited in the salt mine of Altaussee. As such, it was handed over to the representatives of Yugoslavia together with the personal belongings of Ante Pavelić and eventually arrived at the Strossmayer Gallery.

Five paintings that merchant Eugen Kaufmann from Donja Dubrava in Medimurje deposited in 1930 in the safe of the Bank of Yugoslavia passed to the Strossmayer Gallery and the Croatian History Museum when the bank was closed after World War II, since their owner was deported (as Jew) in a concentration camp in 1944. It is known that two portraits of members of noble family of Auersperg, previously owned by Kaufmann and today at the History Museum, come from the castle in Gornja Radgona, and it may be presumed that The Assumption of the Virgin is of the same provenance. On its reverse, it has a mark of the Viennese gilder Franz Xaver Enderle, which points to the art market of Vienna in the mid- $19^{\text {th }}$ century.

The Entombment of Christ by Jacopo Palma the Younger was recorded on the Viennese art market too. In 1920 it was offered for sale as part of the legacy of the Austrian painter Friedrich von Amerling. After that, it was owned by Eduard Polak in Rijeka, who deposited it during the war at the Rijeka Bishopric, whence it was delivered to the Strossmayer Gallery after the war. All these paintings joined the collection of the Strossmayer Gallery by order of Yugoslav federal or republican authorities, at the time when the legal status of the so-called "people's property" was regulated as part of the postwar musealization process.

Keywords: Pieter Jansz. Quast, Dorotheum auction house, Jacques Goudstikker, Jacopo Palma the Younger, Eduard Polak, Friedrich von Amerling, Eugen Kaufmann, castle of Gornja Radgona 